Al-Tanzim : Jurnal Manajemen Pendidikan Islam

E-ISSN: 2549-5720 P-ISSN: 2549-3663

March 2019, Vol. 03 No. 01, p. 1-28

https:// ejournal.unija.ac.id/ index.php/al-tanzim

\title{
PENINGKATAN KOMPETENSI PEDAGODIK GURU MELALUI PELAKSANAAN SUPERVISI KLINIS DENGAN TEKNIK KELOMPOK
}

\author{
Asma Is Babuta ${ }^{1}$, Abdul Rahmat ${ }^{2}$ \\ 1SMP Binaan Kabupaten Pohuwato, \\ ${ }^{2}$ Universitas Negeri Gorontalo \\ abdulrahmat@ung.ac.id
}

\section{Abstract :}

This study aims to find out the picture, find a solution, and increase the pedagogical competence of teachers in 4 junior high schools under the guidance of researchers. The research subjects were Pohuwato district, namely SMPN 2 Wanggarasi, SMPN 2 Dengilo, SMPN 2 Randangan dan SMPN 3 Marisa. Data collection in this study was carried out by observation, and documentation. In this study data validation was done by triangulation technique. Data analysis starts from the field or empirical facts by going into the field, observing, studying, analyzing, interpreting and drawing conclusions. The results showed that the teacher's pedagogical competence increased from 2 teachers or $9.09 \%$ in the pre-cycle, to 10 teachers or $45.45 \%$, and in the last cycle increased to $100 \%$ or all teachers were stated to have increased pedagogical competence. This indicates that clinical supervision by school supervisors has proven effective as an effort to improve teacher pedagogical competencies in the 4 Guidance Middle Schools.

Key Words: Teacher, Pedagogic, Clinical Supervision 
Al-Tanzim : Jurnal Manajemen Pendidikan Islam

E-ISSN: 2549-5720 P-ISSN: 2549-3663

March 2019, Vol. 03 No. 01, p. 1-28

https:/ / ejournal.unuja.ac.id/ index.php/ al-tanzim

\section{Abstrak :}

Penelitian ini bertujuan untuk mengetahui gambaran, mencari solusi, dan meningkat kompetensi pedagogik guru di 4 SMP binaan peneliti. Subjek Penelitian adalah kabupaten Pohuwato yaitu SMPN 2 Wanggarasi, SMPN 2 Dengilo, SMPN 2 Randangan dan SMPN 3 Marisa. Pengumpulan data dalam penelitian ini dilakukan dengan metode observasi, dan dokumentasi. Dalam penelitian ini validasi data dilakukan dengan teknik triangulasi. Analisis data dimulai dari lapangan atau fakta empiris dengan cara terjun ke lapangan, observasi, mengkaji, menganalisis, menafsirkan dan menarik kesimpulan. Hasil penelitian menunjukkan bahwa kompetensi pedagogik guru meningkat dari 2 guru atau 9,09\% pada pra siklus, menjadi 10 orang guru atau 45,45\%, dan pada siklus terakhir meningkat menjadi $100 \%$ atau semua guru dinyatakan meningkat kompetensi pedagogiknya. Hal ini menunjukakn bahwa supervisi klinis dilakukan pengawas sekolah terbukti efektif sebagai upaya meningkatkan kompetensi pedagogik guru di 4 SMP Binaan.

Kata Kunci : Guru, Pedagogik, Supervisi Klinis

\section{PENDAHULUAN}

Untuk melaksanakan Undang-Undang Nomor 20 Tahun 2003 tentang Sistem Pendidikan Nasional, telah ditetapkan Peraturan Pemerintah Nomor 19 Tahun 2005 tentang Standar Nasional Pendidikan yang mencakup standar: (1) isi, (2) proses, (3) kompetensi lulusan, (4) pendidik dan tenaga kependidikan, (5) sarana dan prasarana, (6) pengelolaan, (7) pembiayaan, dan (8) standar penilaian pendidikan. 
Al-Tanzim : Jurnal Manajemen Pendidikan Islam

E-ISSN: 2549-5720 P-ISSN: 2549-3663

March 2019, Vol. 03 No. 01, p. 1-28

https:// ejournal.unuja.ac.id/index.php/al-tanzim

Standar-standar tersebut menjadi acuan dan kriteria dalam peningkatan mutu pendidikan. Standar yang memegang peran penting dan strategis, diantaranya adalah standar pendidik dan tenaga kependidikan. Kepala sekolah/madrasah sebagai pimpinan lembaga merupakan salah satu komponen tenaga kependidikan yang perlu ditingkatkan mutunya khususnya yang berkaitan dengan pelaksanaan proses belajar mengajar.

Selain sebagai tenaga pengajar, guru juga berperan sebagai agen pembelajaran (learning agent). Maksudnya guru tidak hanya berperan sebagai tenaga pengajar an sich, tetapi guru juga multi fungsi, bisa berperan sebagai motivator, fasilitator, perekayasa pembelajaran, inspirator bagi peserta didik, sehingga guru menjadi sosok yang dapat digugu dan ditiru.

Seperti tertuang dalam Undang-undang No. 20 Tahun 2003 tentang Sistem Pendidikan Nasional bahwa pendidik dan tenaga kependidikan memiliki kewajiban untuk: (a) menciptakan suasana pendidikan yang bermakna menyenangkan, kreatif, dinamis, dan dialogis; (b) mempunyai komitmen secara profesional untuk meningkatkan mutu pendidikan; dan (c) memberi teladan dan menjaga nama baik lembaga, profesi, dan kedudukan sesuai dengan kepercayaan yang diberikan kepadanya.

Kompetensi pedagogik ialah kemampuan dalam mengelola pembelajaran yang meliputi pemahaman 
Al-Tanzim : Jurnal Manajemen Pendidikan Islam

E-ISSN: 2549-5720 P-ISSN: 2549-3663

March 2019, Vol. 03 No. 01, p. 1-28

https:/ / ejournal.unuja.ac.id/ index.php/ al-tanzim

terhadap hakikat peserta didik, merancang dan melaksanakan pembelajaran, mengevaluasi hasil belajar dan pengembangan peserta didik untuk mengaktualisaikan berbagai potensi yang dimilikinya. Menurut PP No. 19 Tahun 2005 Pasal 28, ayat 3 dan UU No. 14 Tahun 2005 Pasal 10, ayat 1, kompetensi Guru atau pendidik meliputi: kompetensi profesional, pedagogik, kepribadian, dan sosial (Gorky, 2008).

Kompetensi ini menyangkut kemampuan seorang guru dalam memahami karakteristik atau kemampuan yang dimiliki oleh murid melalui berbagai cara. Cara yang utama yaitu dengan memahami murid melalui perkembangan kognitif murid, merancang pembelajaran dan pelaksanaan pembelajaran serta evaluasi hasil belajar sekaligus pengembangan murid.

Demikian halnya di 4 sekolah binaan peneliti di kabupaten Pohuwato yang terdiri dari 4 SMPN yaitu SMPN 3 Marisa,SMPN 2 Dengilio, SMPN Randanagan dan SMPN 1 Wanggarasi,hampir semua guru kemampuan pedagogiknya masih rendah. Hal tersebut dibuktikan dari hasil penilaian awal siklus diperoleh data dari 22 orang guru di SMPN tersebut hanya 2 guru atau 9,09\% yang dinyatakan memiliki kemampuan pedagogik dalam kriteria tuntas dan sebanyak 20 guru lainnya atau 90,91\% dinyatatakan kemampuan pedagogiknya masih rendah. 
Al-Tanzim : Jurnal Manajemen Pendidikan Islam

E-ISSN: 2549-5720 P-ISSN: 2549-3663

March 2019, Vol. 03 No. 01, p. 1-28

https:// ejournal.unuja.ac.id/index.php/al-tanzim

Sasaran supervisi klinis dalam hal ini adalah guru. Proses pembelajaran dapat terjadi di dalam dan di luar kelas atau di laboratorium. Kelas dalam hal ini dipahami sebagai kelompok belajar peserta didik bukan ruangan belajar. Yang menjadi garapan supervisi klinis dengan teknik kelompok sekurang-kurangnya terdiri atas : (a) perencanaan, penyusunan dan implementasi kurikulum, (b) penyusunan silabus dan rencana pelaksanaan pembelajaran (RPP), (c) pemilihan dan penggunaan strategi pembelajaran (pendekatan, metode, dan teknik), (d) penggunaan media dan teknologi informasi dan komunikasi dalam pembelajaran, (e) merencanakan dan melaksanakan penelitian tindakan kelas.

Kelima aspek tersebut erat kaitannya dengan tugas pokok dan tanggung jawab guru sebagai agen pembelajaran. Karena itu dalam penelitian ini diteliti bagaimana meningkatkan kompetensi pedagogik guru melalui penerapan supervisi klinis dengan teknik kelompok. Oleh sebab itu diperlukan adanya supervisi klinis dengan teknik kelompok yang dilaksanakan oleh Kepala Sekolah dengan mempertimbangkan masalah pembelajaran yang dihadapi guru serta faktor-faktor yang menjadi penyebabnya. 
Al-Tanzim : Jurnal Manajemen Pendidikan Islam

E-ISSN: 2549-5720 P-ISSN: 2549-3663

March 2019, Vol. 03 No. 01, p. 1-28

https: / / ejournal.unuja.ac.id/index.php/al-tanzim

\section{HAKIKAT GURU DALAM PEMBELAJARAN}

Menurut Undang-Undang nomor 20 tahun 2003 tentang Sistem Pendidikan Nasional Pasal 1, mengenai ketentuan umum butir 6, pendidik adalah tenaga kependidikan yang berkualifikasi sebagai guru, dosen, konselor, pamong belajar, widyaiswara, tutor, instruktur, fasilitator, dan sebutan lain yang sesuai dengan kekhususannya. Dengan kata lain, dapat dikatakan bahwa guru adalah pendidik.

Lalu, siapakah guru? Menurut Kamus Besar Bahasa Indonesia (2005), yang dimaksud dengan guru adalah orang yang pekerjaannya (mata pencahariannya, profesinya) mengajar. Pengertian guru menurut KBBI di atas, masih sangat umum dan belum bisa menggambarkan sosok guru yang sebenarnya, sehingga untuk memperjelas gambaran tentang seorang guru diperlukan definisi-definisi lain. Suparlan dalam bukunya yang berjudul -Menjadi Guru Efektifl, mengungkapkan hal yang berbeda tentang pengertian guru.

Menurut Suparlan (2008: 12), guru dapat diartikan sebagai orang yang tugasnya terkait dengan upaya mencerdaskan kehidupan bangsa dalam semua aspeknya, baik spiritual dan emosional, intelektual, fisikal, maupun aspek lainnya. Namun, Suparlan (2008: 13) juga menambahkan bahwa secara legal formal, guru adalah seseorang yang memperoleh surat keputusan (SK), baik dari 
Al-Tanzim : Jurnal Manajemen Pendidikan Islam

E-ISSN: 2549-5720 P-ISSN: 2549-3663

March 2019, Vol. 03 No. 01, p. 1-28

https:// ejournal.unuja.ac.id/index.php/al-tanzim

pemerintah maupun pihak swasta untuk mengajar. Selain pengertian guru menurut Suparlan, Imran juga menambahkan rincian pengertian guru dalam desertasinya.

Menurut Imran (2010), guru adalah jabatan atau profesi yang memerlukan keahlian khusus dalam tugas utamanya seperti mendidik, mengajar, membimbing, mengarahkan, melatih, menilai, dan mengevaluasi siswa pada pendidikan anak usia dini jalur pendidikan formal, pendidikan dasar, dan menengah. Pengertian-pengertian mengenai guru di atas sangat mungkin untuk dapat dirangkum. Jadi, guru adalah seseorang yang telah memperoleh surat keputusan (SK) baik dari pihak swasta atau pemerintah untuk menggeluti profesi yang memerlukan keahlian khusus dalam tugas utamanya untuk mengajar dan mendidik siswa pada pendidikan anak usia dini jalur pendidikan formal, pendidikan dasar, dan menengah, yang tujuan utamanya untuk mencerdaskan bangsa dalam semua aspek.

\section{SUPERVISI KLINIS DALAM PENDIDIKAN}

Menurut Nerney dalam Sahertian (2000) supervisi dipandang sebagai suatu prosedur memberi arah serta mengadakan penilaian secara kritis terhadap proses pengajaran. Menurut Acheson dan Gall dalam Techniques in the Clinical Supervision of Teachers, (1980) mengemukakan bahwa : "Supervision ... to help the teacher improve his or her 
Al-Tanzim : Jurnal Manajemen Pendidikan Islam

E-ISSN: 2549-5720 P-ISSN: 2549-3663

March 2019, Vol. 03 No. 01, p. 1-28

https:/ / ejournal.unuja.ac.id/ index.php/ al-tanzim

instructional performance".

Dalam hal ini, ia menekankan pada bantuan dalam hal perbaikan performa mengajar guru. Adam dan Dicky dalam Basic Principles of Supervision (1953 : 5) menyatakan : "Supervision is a service particulary concerned with instruction and it's improvement. It is directly concerned with teaching and learning and with factors included in and related to these process teaches, pupils, curriculum, material of instruction social ophusical environment of the situation".

Definisi tersebut memberikan makna bahwa, supervisi lebih menekankan dalam bentuk pelayanan. Sasaran utama supervisi adalah belajar mengajar, serta usaha untuk memperbaiki.

Boardman (2000) menyatakan bahwa supervisi merupakan usaha menstimuli, mengkoordinasi dan membimbing secara kontinu pertumbuhan guru-guru di sekolah baik secara individual maupun secara kolektif, agar lebih mengerti dan lebih efektif dalam mewujudkan seluruh fungsi pengajaran sehingga mereka lebih dimungkinkan mendorong demokrasi modern. Tekanannya dalam bentuk pengelolaan supervisi dengan menggunakan teknik supervisi.

Menurut Rifai (2001), supervisi pendidikan dipahami sebagai bimbingan, pelayanan dan bantuan dari supervisor kepada yang disupervisi (pada umumnya guru), supaya para guru itu meningkat keahlian profesionalnya, dapat 
Al-Tanzim : Jurnal Manajemen Pendidikan Islam

E-ISSN: 2549-5720 P-ISSN: 2549-3663

March 2019, Vol. 03 No. 01, p. 1-28

https:// ejournal.unuja.ac.id/index.php/al-tanzim

menjadi guru yang lebih baik dan menghasilkan murid yang lebih baik pula.

Supervisi klinis sebagai bagian dari model supervisi menurut Willem (dalam Acheson dan Gall, 1980) adalah bentuk supervisi yang difokuskan pada peningkatan mengajar dengan melalui siklus yang sistematik, dalam perencanaan, pengamatan serta analisis yang intensif dan cermat tentang penampilan mengajar yang nyata, serta bertujuan mengadakan perubahan dengan cara yang rasional (Sahertian, 2000).

Sergiovanni (2003) menyatakan bahwa pembinaan guru dengan pendekatan klinik adalah suatu pertemuan tatap muka antara pembina dengan guru, membahas tentang hal mengajar di dalam kelas guna perbaikan pengajaran dan pengembangan profesi.

Dari beberapa pendapat di atas, dapat disimpulkan bahwa supervisi klinis adalah salah satu bentuk supervisi yang difokuskan pada upaya peningkatan sistem pembelajaran yang baik dan sistematik dan memperkecil kesenjangan antara tingkah laku mengajar yang nyata dengan tingkah laku mengajar yang ideal melalui observasi dan analisis data secara objektif. 
Al-Tanzim : Jurnal Manajemen Pendidikan Islam

E-ISSN: 2549-5720 P-ISSN: 2549-3663

March 2019, Vol. 03 No. 01, p. 1-28

https:// ejournal.unuja.ac.id/index.php/al-tanzim

\section{METODE PENELITIAN}

Penelitian ini merupakan Penelitian Tindakan Kepengawasan. Penelitian ini mengambil bentuk Penelitian Tindakan Sekolah (PTS) yaitu kemampuan pedagogik guru SMP di wilayah binaan yang dilaksanakan dalam 2 siklus dan masing masing siklus terdiri dari 4 tahap yaitu : (1) tahap perencanaan program tindakan, (2) pelaksanaan program tindakan, (3) pengamatan program, (4) refleksi.

Subyek dalam penelitian ini adalah guru SMP di wilayah Binaan peneliti sebanyak 22 guru yaitu guru PKn dan IPS di SMPN 3 Marisa, SMPN 2 Randangan, SMPN 2 Dengilo dan SMPN 1 Wanggarasi.

\section{Tabel. 1}

Pedoman Penilaian Kompetensi pedagogik Guru

\begin{tabular}{|c|l|c|c|}
\hline NO & \multicolumn{1}{|c|}{ K O M P E T E N S I } & NILAI & $\begin{array}{c}\text { KONVERSI } \\
\text { NILAI }\end{array}$ \\
\hline 1 & $\begin{array}{l}\text { Mengenal karakteristik } \\
\text { peserta didik }\end{array}$ & $\begin{array}{l}\text { Menguasai teori belajar dan } \\
\text { prinsip-prinsip pembelajaran } \\
\text { yang mendidik }\end{array}$ & \\
\hline 3 & Pengembangan kurikulum & \\
\hline 4 & $\begin{array}{l}\text { Kegiatan pembelajaran yang } \\
\text { mendidik }\end{array}$ & $\begin{array}{l}\text { Memahami dan } \\
\text { mengembangkan potensi }\end{array}$ & \\
\hline 5 & & \\
\hline
\end{tabular}


Al-Tanzim : Jurnal Manajemen Pendidikan Islam

E-ISSN: 2549-5720 P-ISSN: 2549-3663

March 2019, Vol. 03 No. 01, p. 1-28

https:// ejournal.unija.ac.id/ index.php/al-tanzim

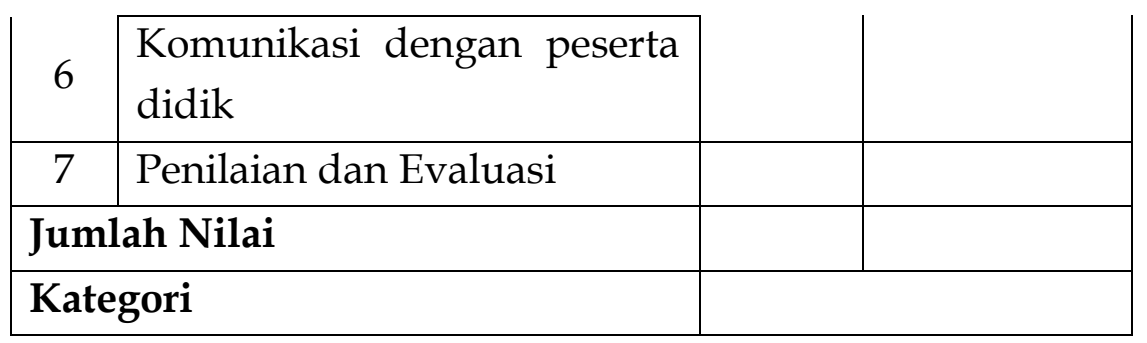

*) Nilai minimum per kompetensi = 0 dan Nilai Maksimum 5

\begin{tabular}{|l|c|}
\hline Rentang & Kategori \\
\hline $91-100$ & Amat Baik \\
\hline $76-90$ & Baik \\
\hline $61-75$ & Cukup \\
\hline $51-60$ & Sedang \\
\hline$<50$ & Kurang \\
\hline
\end{tabular}

Analisis data dilakukan secara induktif, yaitu dimulai dari lapangan atau fakta empiris dengan cara terjun ke lapangan, mempelajari, menganalisis, menafsirkan dan menarik kesimpulan dari fenomena yang ada di lapangan. Analisis data dalam penelitian kualitatif dilakukan bersamaan dengan proses pengumpulan data.

Penilaian terhadap peningkatan kompetensi pedagogik guru diamati dan diobservasi dengan penjelasan sebagai berikut : 
Al-Tanzim : Jurnal Manajemen Pendidikan Islam

E-ISSN: 2549-5720 P-ISSN: 2549-3663

March 2019, Vol. 03 No. 01, p. 1-28

https:/ / ejournal.unuja.ac.id/ index.php/ al-tanzim

Skor 1 = Ada dokumen tidak lengkap, tidak dikerjakan

Skor 2 = Ada dokumen tidak lengkap, dikerjakan tidak lengkap

Skor 3 = Ada dokumen lengkap, dikerjakan, tidak lengkap

Skor 4 = Ada dokumen lengkap, dikerjakan, lengkap

Sedangkan untuk menghitung nilai kualifikasi digunakan rumus sebagai berikut :

Jumlah skor perolehan

Nilai Kualifikasi $=$ $X 100$

Jumlah skor nilai ideal

Adapun indikator keberhasilan dalam penelitian ini adalah pelaksanaan kegiatan supervisi klinis pada guru PKn dan IPS di SMPN 3 Marisa, SMPN 2 Randangan, SMPN 2 Dengilo dan SMPN 1 Wanggarasi. Proses kegiatan penelitian dilakukan dengan dua siklus dimana masingmasing siklus terdiri dari atas 4 tahapan yakni perencanaan, pelaksanaan, observasi dan refleksi. Indikator kinerja dalam penelitian ini adalah bila minimal skor 76-90 (BAIK) sudah dapat dikatakan tindakan yang diterapkan berhasil. Aspek yang diukur adalah peningkatan kompetensi pedagogik guru yang diwujudkan dalam lembar observasi dengan kriteria keberhasilan minimal $85 \%$ guru meningkat kompetensi pedagogiknya. 
Al-Tanzim : Jurnal Manajemen Pendidikan Islam

E-ISSN: 2549-5720 P-ISSN: 2549-3663

March 2019, Vol. 03 No. 01, p. 1-28

https:/ / ejournal.unuja.ac.id/ index.php/ al-tanzim

\section{HASIL PENELITIAN DAN PEMBAHASAN}

Dari pelaksanaan kegiatan penelitian yang dilaksanakan dalam 2 siklus dengan melaksanakan kegiatan penilaian kompetensi pedagogik guru kepada 22 guru melalui pelaksanaan supervisi akademik di 4 sekolah binaan peneliti yang terdiri dari SMPN 3 Marisa, SMPN 2 Randangan, SMPN 2 Dengilo dan SMPN 1 Wanggarasi. Evaluasi dilakukan setelah proses pembelajaran selesai dengan menjumlahkan skor perolehan masing-masing guru yang ada dalam lembar obsevasi yang terdiri dari 45 butir deskriptor, masing-masing deskriptor diberi skor/nilai 1 - 4 dapat disjikan sebagai berikut :

\section{Kondisi Awal}

Dengan padatnya kegiatan seorang guru di sekolah, baik yang berhubungan dengan permasalahan manajemen di sekolah maupun di luar sekolah menyebabkan seorang guru kurang bisa maksimal bahkan mungkin tidak dijalankan sama menjalan tugasnya sebagai seorang pendidik Hal tersebut menjadikan perhatian khusus bagi peneliti karena pada prinsipnya guru adalah seorang guru yang diharuskan memiliki kemampuan yang memadai dalam kegiatan belajar mengajar. Oleh sebab itu maka peneliti yang juga menjadi pengawas pembina di SMPN 3 Marisa, SMPN 2 Randangan, SMPN 2 Dengilo dan SMPN 1 Wanggarasi merasa ikut dan harus bertanggung jawab 
Al-Tanzim : Jurnal Manajemen Pendidikan Islam

E-ISSN: 2549-5720 P-ISSN: 2549-3663

March 2019, Vol. 03 No. 01, p. 1-28

https:/ / ejournal.unuja.ac.id/ index.php/ al-tanzim

untuk meningkatkan kompetensi mengajar para guru khususnya kompetensi pedagogik.

Untuk mengukur kompetensi pedagogik guru perlu dipersiapkan lembar observasi. Angket diadopsi dari Lampiran Penilaian Kompetensi Guru. Lembar observasi ini berisi 7 (tujuh) indikator dengan 45 deskriptor, yaitu indikator pertama, mengenal karakteristik peserta didik terdiri dari 6 deskriptor, indikator kedua, menguasai teori belajar dan prinsip-prinsip pembelajaran yang mendidik terdiri dari 6 deskriptor, indikator ketiga, Pengembangan kurikulum terdiri dari 4 deskriptor, Indikator keempat, Kegiatan pembelajaran yang mendidik terdiri dari 11 deskriptor, indikator kelima, Memahami dan mengembangkan potensi terdiri dari 7 deskriptor, indikator keenam, Komunikasi dengan peserta didik terdiri dari 6 deskriptor, indikator ketujuh, Penilaian dan Evaluasi terdiri dari 5 deskriptor.

Lembar observasi ini digunakan oleh Pengawas Sekolah sebagai daftar penilaian terhadap kompetensi pedagogik guru. Skala nilai adalah 1 - 4 dengan ketentuan sebagai berikut: Nilai 4 jika ada dokumen lengkap, dikerjakan, lengkap, nilai 3 jika ada dokumen lengkap, dikerjakan, tidak lengkap, nilai 2 jika ada dokumen tidak lengkap, dikerjakan tidak lengkap, nilai 1 jika ada dokumen tidak lengkap, tidak dikerjakan 
Al-Tanzim : Jurnal Manajemen Pendidikan Islam

E-ISSN: 2549-5720 P-ISSN: 2549-3663

March 2019, Vol. 03 No. 01, p. 1-28

https:// ejournal.unija.ac.id/ index.php/al-tanzim

Tabel. 2

Rekapitulasi Hasil Penilaian Kompetensi pedagogik pada

Kondisi Awal Berdasarkan Kategori Penilaian

\begin{tabular}{|c|c|c|c|c|c|}
\hline \hline No & Rentang & Kategori & Jumlah & Persentase & Ket \\
\hline 1 & $91-100$ & Amat Baik & 0 & 0,00 & \\
\hline 2 & $76-90$ & Baik & 2 & 9,09 & \\
\hline 3 & $61-75$ & Cukup & 1 & 4,55 & \\
\hline 4 & $51-60$ & Sedang & 6 & 27,27 & \\
\hline 5 & $<50$ & Kurang & 13 & 59,09 & \\
\hline \hline
\end{tabular}

Dari data di atas dapat ditarik kesimpulan bahwa pada prinsipnya, pelaksanaan kegiatan penilaian kompetensi pedagogik yang dilakukan kepada 22 guru di SMPN 3 Marisa, SMPN 2 Randangan, SMPN 2 Dengilo dan SMPN 1 Wanggarasi. belum sepenuhnya memenuhi standar minimal yang ditetapkan, karena dari 22 orang guru hanya ada 2 guru atau 9,09\% yang dinyatakan kompetensi pedagogiknya berada dalam kriteria minimal BAIK.

Untuk memperjelas, Rekapitulasi Hasil Penilaian Kompetensi pedagogik pada Siklus Pertama Berdasarkan Kategori Penilaian dalam bentuk diagram batang sebagaimana gambar di bawah ini. 
Al-Tanzim : Jurnal Manajemen Pendidikan Islam

E-ISSN: 2549-5720 P-ISSN: 2549-3663

March 2019, Vol. 03 No. 01, p. 1-28

https:// ejournal.unuja.ac.id/ index.php/al-tanzim

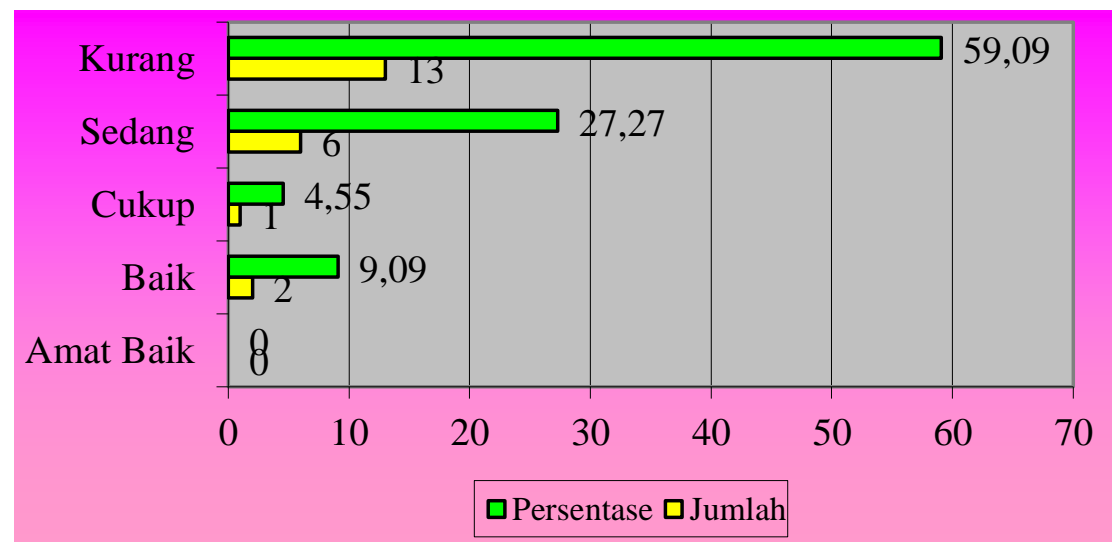

Gambar. 1

Grafik Peningkatan Kompetensi pedagogik pada Siklus Pertama

\section{Siklus I}

Pengamatan dilakukan selama proses pembelajaran berlangsung yang dilakukan oleh pengawas sekolah terdiri dari penilaian proses pembelajaran dan administrasi perangkat pembelajaran, yang terdiri dari bukti fisik perlengkapan pembelajaran (prota, promes, Silabus, RPP, bahan ajar, analisis hasil belajar siswa. Pengawas sekolah memantau secara langsung di dalam ruang belajar. Evaluasi dilakukan setelah proses pembelajaran selesai dengan menjumlahkan skor perolehan yang ada dalam lembar obsevasi yang terdiri dari 45 butir deskriptor, masingmasing deskriptor diberi skor/nilai $1-4$.

Dari data yang didapatkan, dapat ditarik kesimpulan bahwa pada prinsipnya, pelaksanaan kegiatan penilaian kompetensi pedagogik yang dilakukan kepada 22 orang 
Al-Tanzim : Jurnal Manajemen Pendidikan Islam

E-ISSN: 2549-5720 P-ISSN: 2549-3663

March 2019, Vol. 03 No. 01, p. 1-28

bttps: / / ejournal.unuja.ac.id/ index.php/ al-tanzim

guru berjalan dengan efektif, walaupun secara keseluruhan hasil yang diharapkan belum tercapai, karena dari 22 orang guru terdapat 10 orang guru $45,45 \%$ yang dinyatakan kompetensi pedagogiknya meningkat bila dibandingkan dengan kondisi awal sebelum pelaksanaan kegiatan penilaian kompetensi pedagogik dilakukan.

Dari pelaksanaan kegiatan penilaian kompetensi pedagogik terhadap guru pada pelaksanaan siklus pertama dapat dirangkum sebagaimana tabel di bawah ini.

Tabel. 3

Rekapitulasi Hasil Penilaian Kompetensi pedagogik pada Siklus Pertama Berdasarkan Kategori Penilaian

\begin{tabular}{|c|c|c|c|c|c|}
\hline \hline No & Rentang & Kategori & Jumlah & Persentase & Ket \\
\hline 1 & $91-100$ & Amat Baik & 1 & 4,55 & \\
\hline 2 & $76-90$ & Baik & 9 & 40,91 & \\
\hline 3 & $61-75$ & Cukup & 10 & 45,45 & \\
\hline 4 & $51-60$ & Sedang & 2 & 9,09 & \\
\hline 5 & $<50$ & Kurang & 0 & 0,00 & \\
\hline
\end{tabular}

Untuk memperjelas, Rekapitulasi Hasil Penilaian Kompetensi pedagogik pada Siklus Pertama Berdasarkan Kategori Penilaian dalam bentuk diagram batang sebagaimana gambar di bawah ini. 
Al-Tanzim : Jurnal Manajemen Pendidikan Islam

E-ISSN: 2549-5720 P-ISSN: 2549-3663

March 2019, Vol. 03 No. 01, p. 1-28

https:// ejournal.unuja.ac.id/ index.php/ al-tanzim

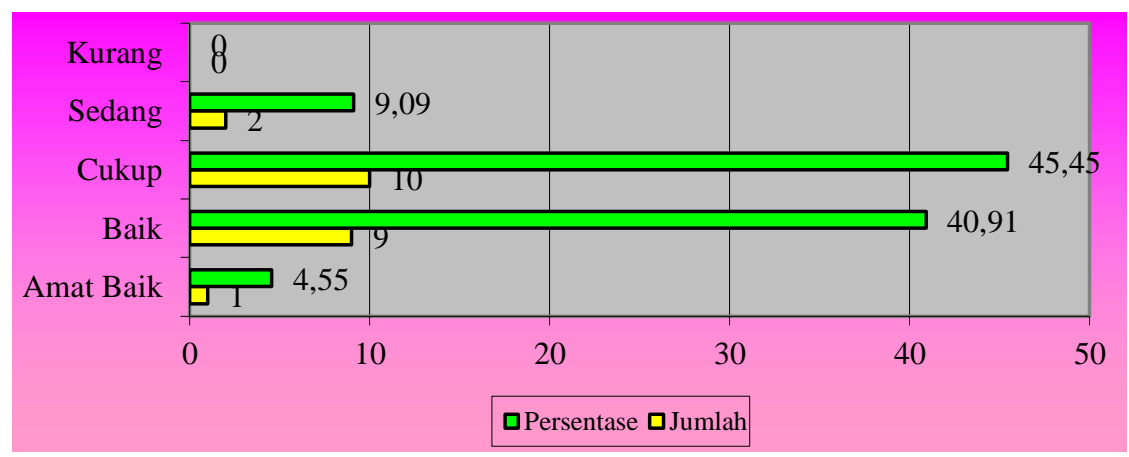

Gambar. 2

Grafik Peningkatan Kompetensi pedagogik pada Siklus Pertama

\section{Siklus II}

Pengamatan dilakukan selama proses pembelajaran berpedoman kepada lembar observasi (angket) yang disediakan. Evaluasi dilakukan setelah proses pembelajaran selesai dengan menjumlahkan skor perolehan masingmasing guru yang ada dalam lembar obsevasi yang terdiri dari 45 butir deskriptor, masing-masing deskriptor diberi skor/nilai $1-4$.

Dari data yang didapat, dapat ditarik kesimpulan bahwa pada prinsipnya, pelaksanaan kegiatan penilaian kompetensi pedagogik yang dilakukan kepada 22 guru berjalan dengan dengan baik, secara keseluruhan hasil yang diharapkan sudah tercapai, karena dari 22 orang guru yang dinyatakan kompetensi pedagogiknya meningkat dengan kategori BAIK sebanyak 10 orang atau 45,45\% dan AMAT BAIK sebanyak 54,55\% atau 12 orang guru. Dari hasil 
Al-Tanzim : Jurnal Manajemen Pendidikan Islam

E-ISSN: 2549-5720 P-ISSN: 2549-3663

March 2019, Vol. 03 No. 01, p. 1-28

https:// ejournal.unija.ac.id/ index.php/al-tanzim

tersebut dapat disimpulkan bahwa indikator dan kriteria keberhasilan telah tercapai pada pelaksanaan siklus kedua, yaitu minimal 85\% meningkat kompetensi pedagogiknya.

Dari pelaksanaan kegiatan penilaian kompetensi pedagogik terhadap guru pada pelaksanaan siklus pertama dapat dirangkum sebagaimana tabel di bawah ini.

Tabel. 4

Rekapitulasi Hasil Penilaian Kompetensi pedagogik pada Siklus Kedua Berdasarkan Kategori Penilaian

\begin{tabular}{|c|c|c|c|c|c|}
\hline \hline No & Rentang & Kategori & Jumlah & Persentase & Ket \\
\hline 1 & $91-100$ & Amat Baik & 12 & 54,55 & \\
\hline 2 & $76-90$ & Baik & 10 & 45,45 & \\
\hline 3 & $61-75$ & Cukup & 0 & 0,00 & \\
\hline 4 & $51-60$ & Sedang & 0 & 0,00 & \\
\hline 5 & $<50$ & Kurang & 0 & 0,00 & \\
\hline \hline
\end{tabular}

Untuk memperjelas, Rekapitulasi Hasil Penilaian Kompetensi pedagogik pada Siklus Pertama Berdasarkan Kategori Penilaian dalam bentuk diagram batang sebagaimana gambar di bawah ini; 
Al-Tanzim : Jurnal Manajemen Pendidikan Islam

E-ISSN: 2549-5720 P-ISSN: 2549-3663

March 2019, Vol. 03 No. 01, p. 1-28

https:// ejournal.unija.ac.id/ index.php/al-tanzim

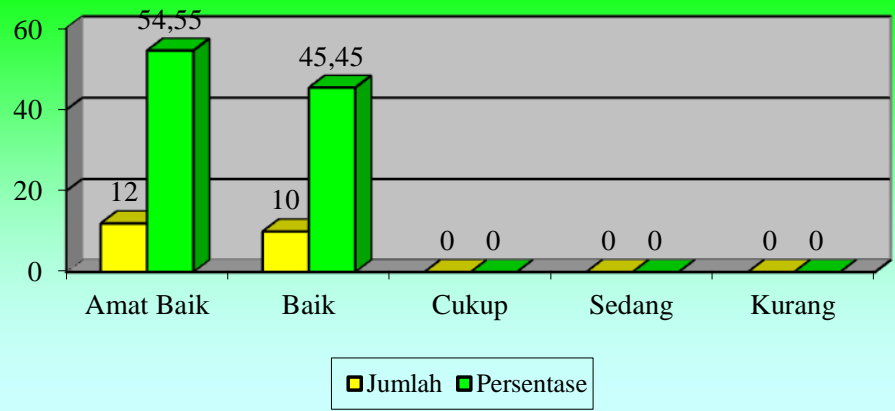

Gambar. 3

Grafik Peningkatan Kompetensi pedagogik pada Siklus Kedua

\section{PEMBAHASAN}

Dari pelaksanaan kegiatan penilaian kompetensi pedagogik terhadap guru pada pelaksanaan siklus pertama dapat dirangkum sebagaimana tabel di bawah ini;

\section{Tabel 5}

Rekapitulasi Hasil Penilaian Kompetensi pedagogik pada Kondisi Awal, Siklus Pertama dan Siklus Kedua

\begin{tabular}{|c|c|c|c|c|c|c|}
\hline \hline \multirow{2}{*}{ No } & \multirow{2}{*}{ Siklus } & \multicolumn{4}{|c|}{ Kriteria Ketuntasan } & \multirow{2}{*}{ Ket } \\
\cline { 3 - 6 } & & \multicolumn{2}{|c|}{ Tuntas } & \multicolumn{2}{c|}{ Belum Tuntas } & \\
\cline { 3 - 6 } & $\mathbf{F}$ & $\mathbf{0}$ & $\mathbf{F}$ & $\mathbf{0}$ & \\
\hline 1 & Awal & 2 & 9,09 & 20 & 90,91 & \\
\hline 2 & Siklus I & 10 & 45,45 & 12 & 54,55 & \\
\hline 3 & Siklus II & 22 & 100,00 & 0 & 0,00 & \\
\hline \hline
\end{tabular}


Al-Tanzim : Jurnal Manajemen Pendidikan Islam

E-ISSN: 2549-5720 P-ISSN: 2549-3663

March 2019, Vol. 03 No. 01, p. 1-28

bttps: / / ejournal.unuja.ac.id/ index.php/ al-tanzim

Untuk memperjelas, Rekapitulasi Hasil Penilaian Kompetensi pedagogik pada Siklus Pertama Berdasarkan Kategori Penilaian dalam bentuk diagram batang sebagaimana gambar di bawah ini.

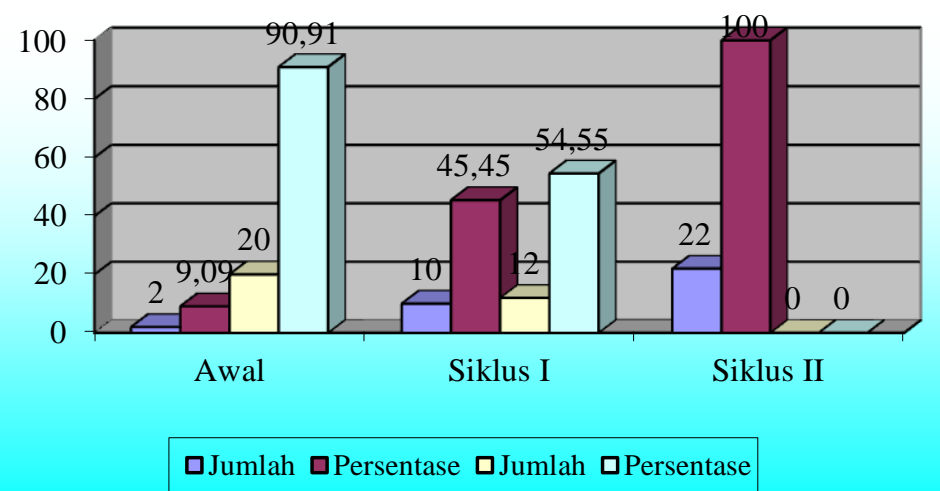

Gambar. 4

Peningkatan Kompetensi Pedagogik pada Kondisi Awal, Siklus I dan Siklus II

Dari hasil pelaksanaan kegiatan awal penelitian yang dilakukan kepada 22 guru di 4 sekolah binaan peneliti yang terdiri dari SMPN 3 Marisa, SMPN 2 Randangan, SMPN 2 Dengilo dan SMPN 1 Wanggarasi. belum sepenuhnya memenuhi standar minimal yang ditetapkan, karena dari 22 orang guru hanya ada 2 guru atau 9,09\% yang dinyatakan kompetensi pedagogiknya berada dalam kriteria minimal BAIK. Dari data hasil pelaksanaan siklus pertama dapat ditarik kesimpulan bahwa pada prinsipnya, 
Al-Tanzim : Jurnal Manajemen Pendidikan Islam

E-ISSN: 2549-5720 P-ISSN: 2549-3663

March 2019, Vol. 03 No. 01, p. 1-28

bttps:// ejournal.unuja.ac.id/index.php/al-tanzim

pelaksanaan kegiatan penilaian kompetensi pedagogik yang dilakukan kepada 22 orang guru berjalan dengan efektif, walaupun secara keseluruhan hasil yang diharapkan belum tercapai, karena dari 22 orang guru terdapat 10 orang guru $45,45 \%$ yang dinyatakan kompetensi pedagogiknya meningkat bila dibandingkan dengan kondisi awal sebelum pelaksanaan kegiatan penilaian kompetensi pedagogik dilakukan.

Dari data hasil pelaksanaan siklus pertama dapat ditarik kesimpulan bahwa pada prinsipnya, pelaksanaan kegiatan penilaian kompetensi pedagogik yang dilakukan kepada 22 orang guru berjalan dengan dengan baik, secara keseluruhan hasil yang diharapkan sudah tercapai, karena dari 22 orang guru yang dinyatakan kompetensi pedagogiknya meningkat dengan kategori BAIK sebanyak 10 orang atau $45,45 \%$ dan AMAT BAIK sebanyak 54,55\% atau 12 orang guru. Dari hasil tersebut dapat disimpulkan bahwa indikator dan kriteria keberhasilan telah tercapai pada pelaksanaan siklus kedua, yaitu minimal 85\% meningkat kompetensi pedagogiknya.

Adanya peningkatan kompetensi pedagogik guru yang mendapat tugas sebagai guru mata pelajaran ini juga terkait erat dengan partisipasi guru dalam mengikuti pelaksanaan supervisi klinis yang dilakukan oleh pengawas. Tingginya aktivitas guru dalam mengikuti kegiatan supervisi klinis secara aktif terlibat memberikan kontribusi yang nyata 
Al-Tanzim : Jurnal Manajemen Pendidikan Islam

E-ISSN: 2549-5720 P-ISSN: 2549-3663

March 2019, Vol. 03 No. 01, p. 1-28

https:// ejournal.unuja.ac.id/index.php/al-tanzim

terhadap kompetensi pedagogik dalam melaksanakan pembelajaran. Hal ini berarti bahwa pelaksanaan supervisi klinis mampu mendorong guru untuk terus meningkatkan kompetensi pedagogiknya.

Hal ini disebabkan karena partisipasi guru dalam pelaksanaan supervisi klinis akan bersentuhan langsung dengan kegiatan-kegiatan pembelajaran yang dilaksanakan di dalam kelas baik mengenai kelengkapan administrasi mengajar maupun proses pelaksanaan kegiatan pembelajarannya. Supervisi klinis yang dilaksanakan pada prinsipnya memiliki tujuan dan semangat maju bersama dalam meningkatkan mutu pendidikan melalui penerapan sistem pembinaan profesional. Sistem pembinaan profesional diberikan pada guru dengan penekanan pada bantuan pelayanan profesi berdasarkan kebutuhan guruguru di lapangan. Tujuannya adalah untuk meningkatkan kemampuan profesional guru sekolah dasar dalam meningkatkan mutu proses dan hasil belajar dengan mendayagunakan segala sumber daya dan potensi yang dimiliki. Keterlibatan dalam pelaksanaan supervisi klinis diharapkan dapat memberikan informasi yang berguna bagi peningkatan kualitas pembelajaran karena kegiatan supervisi klinis tersebut banyak membahas masalahmasalah yang dialami guru dalam pembelajaran untuk dipecahkan secara bersama-sama sehingga meningkatkan semangat dalam rangka mengembangkan pembelajaran. 
Al-Tanzim : Jurnal Manajemen Pendidikan Islam

E-ISSN: 2549-5720 P-ISSN: 2549-3663

March 2019, Vol. 03 No. 01, p. 1-28

https:/ / ejournal.unuja.ac.id/ index.php/ al-tanzim

Kegiatan-kegiatan inilah yang bersentuhan secara langsung dengan guru dalam rangka meningkatkan profesionalisme guru.

Berdasarkan hasil-hasil pelaksanaan kegiatan penelitian tindakan sekolah yang dilaksanakan maka dapat ditarik kesimpulan akhir bahwa kegiatan penelitian dinyatakan selesai dan tuntas pada siklus kedua, karena semua indikator penelitian telah tercapai.

\section{KESIMPULAN}

Dengan mempertimbangkan dan merujuk pada simpulan sebagaimana dijelaskan di atas dan kenyataan yang ada di lapangan, maka peneliti menyarankan beberapa hal yang berkaitan dengan hasil penelitian yang telah dilaksanakan antara lain (1) Penelitian perlu dilanjutkan dengan serangkaian penelitian yang mengembangkan alat ukur keberhasilan yang lebih reliabel agar dapat menggambarkan peningkatan semua aspek-aspek kompetensi guru dengan baik sehingga mutu pendidikan dapat ditingkatkan. (2) Kegiatan penilaian melalui pelaksanaan supervisi klinis terhadap guru dengan melaksanakan kegiatan penilaian kompetensi pedagogik guru diperlukan perhatian penuh dan disiplin yang tinggi pada setiap langkah dan perencanaan yang matang misalnya dalam pengalokasian waktu dan pemilihan konsep yang sesuai. (3) Kepada guru diharapkan selalu 
Al-Tanzim : Jurnal Manajemen Pendidikan Islam E-ISSN: 2549-5720 P-ISSN: 2549-3663

March 2019, Vol. 03 No. 01, p. 1-28 https:/ / ejournal.unija.ac.id/ index.php/al-tanzim

mengikuti perkembangan zaman, terutama dengan membaca hasil karya para ahli sehingga tidak ketinggalan dengan daerah lain, dalam meningkatkan mutu pendidikan, sebagai tanggung jawab bersama memajukan pendidikan 
Al-Tanzim : Jurnal Manajemen Pendidikan Islam

E-ISSN: 2549-5720 P-ISSN: 2549-3663

March 2019, Vol. 03 No. 01, p. 1-28

bttps:/ / ejournal.unuja.ac.id/ index.php/ al-tanzim

\section{DAFTAR PUSTAKA}

Acheson, K. A., \& Gall, M. D. (1980). Techniques in the clinical supervision of the teachers: Preservice and inservice applications (4th ed.). White Palins, NY: Longman.

Adam and Dickey. (1953). Basic Principle of Supervision, New York, American Book Company.

Danim, Sudarman dan Suparno. (2002). Manajemen dan Kepemimpinan Transformasional Kepala Sekolahan, Jakarta: Rineka Cipta

Depdiknas. (2007). Peraturan Menteri Pendidikan Nasional Nomor 13 Tahun 2007, Tentang Standar Kepala Sekolah/Madrasah. Jakarta: Depdiknas

Depdiknas. (2008). Permendiknas No.16 tahun 2007 tentang Standar Kualifikasi dan Kompetensi Guru. Depdiknas: Jakarta.

J. Mursell dan S. Nasution. (1996). Mengajar Dengan Sukses, Bandung: PN. Jemmars

Madyo Ekosusilo. (2003). Hasil Penelitian Kualitatif Sekolah Unggul Berbasis Nilai. Semarang: Penerbit Effhar.

Moeleong, Lexy J. (2008). Teknik Penelitian Kualitatif. Bandung : Remaja Rosdakarya.

Moleong, L. J. (2004). Metodologi Penelitian Kualitatif, Bandung : PT Remaja Rosdakarya.

Munir, Abdullah. (2008). Menjadi Kepala Sekolah Efektif. Jogjakarta: Ar-Ruzz Media 
Al-Tanzim : Jurnal Manajemen Pendidikan Islam

E-ISSN: 2549-5720 P-ISSN: 2549-3663

March 2019, Vol. 03 No. 01, p. 1-28

https:// ejournal.unuja.ac.id/index.php/al-tanzim

Munir. (2008). Kurikulum Berbasis Teknologi Informasi dan Komunikasi. Bandung: Alfabeta

Nana Sudjana dan Ahmad Rivai. (2001). Media Pengajaran. Bandung: Sinar Baru.

Payong, Marselus R. (2011). Sertifikasi Profesi Guru. Jakarta: PT Indeks.

Peraturan Menteri Pendidikan Nasional Nomor 13 Tahun (2007). Kompetensi Kepala Sekolah/Madrasah. Bandung: Rosda Karya.

Peraturan Menteri Pendidikan Nasional Nomor 28 Tahun

2010 tentang Penugasan Guru sebagai Kepala Sekolah/ Madrasah. Jakarta : Depdiknas

Permana, Johar, dan Kesuma, Darma. (2009). Kepemimpinan

Pendidikan; dalam Riduwan, Ed, Manajemen

Pendidikan .Bandung: Alfabeta

Rachman, Maman. (1999). Strategi dan Langkah-langkah

Penelitian. Semarang: IKIP Semarang Press

Rifa 'I, Achmad dan Catharina Tri Anni. (2011). Psikologi Pendidikan, Semarang :UNNES Press

Sahertian, Piet A. (2000). Konsep Dasar dan Tehnik Supervisi Pendidikan Dalam Rangka Mengembangkan Sumber Daya Manusia, Jakarta : Rineka Cipta

Sarimaya, Farida. (2008). Sertifikasi Guru, Apa, Mengapa dan Bagaimana?, Bandung: Penerbit Yrama Widya. 
Al-Tanzim : Jurnal Manajemen Pendidikan Islam

E-ISSN: 2549-5720 P-ISSN: 2549-3663

March 2019, Vol. 03 No. 01, p. 1-28

bttps:/ / ejournal.unuja.ac.id/ index.php/ al-tan₹im

Trianto dan Tutik TT. (2007). Sertifikasi Guru dan Upaya Peningkatan Kulifikasi Kompetensi dan Kesejahteraan. Prestasi Pustaka. Jakarta.

Trianto. (2008), Oktober. Branding Sekolah Yes, Komersial Sekolah No. Media..

Undang-Undang Republik Indonesia No. 14 Tahun 2005 Tentang Guru dan Dosen. Bandung: Citra Umbara

Undang-undang Republik Indonesia Nomor 20 Tahun 2003 tentang Sistem Pendidikan Nasional

Wahjosumidjo. (1999). Kepemimpinan Kepala Sekolah: Tinjauan Teoritik dan Permasalahannya. Jakarta: Rajawali Pers. 